\title{
Çocuk Acil Kliniğimizde Takip Edilen Hastalarda Solunum Yolu Viral Etkenlerin Dağılımı
}

\author{
Esra TÜRE ${ }^{1}$, Abdullah YAZAR ${ }^{1}$
}

\begin{abstract}
Öz
Solunum yolu enfeksiyonu bulguları ile çocuk acil polikliniğine başvuran ve çocuk acil yataklı ünitesinde takip edilen 5 yaş altı hastaların nazofaringeal sürüntü örneklerinde saptanan solunum yolu virüslerinin görülme sıklığının, mevsim, yaş ve klinik bulgulara göre dağılımının saptanması amaçlandı. Hastaların kayıtları retrospektif olarak incelendi ve yaş, cinsiyet, başvuru şikayeti, fizik muayene bulguları, başvurduğu mevsim, non-invaziv ventilasyon gereksinimi, hastanede yatış süresi, nazofaringeal sürüntü viral polimeraz zincir reaksiyonu (PCR) inceleme sonuçları kaydedildi. Nazofaringeal sürüntü viral PCR sonuçları incelendiğinde hastaların 43'ünde $(\% 26,5)$ herhangi bir virüs izole edilemediği, 119'unda $(\% 73,5)$ ise en az bir ya da birden fazla virüs izole edildiği görüldü. Bu 119 hastanın 82 'sinde $(\% 68,9)$ tek bir virüs, 37 'sinde $(\% 31,1)$ iki veya daha fazla virüs izole edildi. Hastaların aldıkları tedavileri incelendiğinde 87'sinin $(\% 53,7)$ hiçbir antibiyotik almadığ 1 , 75 'inin $(\% 46,3)$ ise bir ya da birden çok antbiyotik tedavisi aldığ erken dönemde saptanması ile gereksiz antibiyotik kullanımının önlenebileceği, antibiyotik direncinin kontrol altına alınabileceği, hastanede yatış süresinin kısalacağı ve tedavi maliyetlerinin azalacağı düşünülmektedir.
\end{abstract}

Anahtar Kelimeler: Solunum yolu enfeksiyonu, nazofaringeal sürüntü, viral PCR, çocuk

Yayın Bilgisi

Gönderi Tarihi:11.12.2018

Kabul Tarihi: 02.01.2019

Online Yayın Tarihi: 31.03.2019

DOI: $10.26453 /$ otjhs.495639

Sorumlu Yazar

Esra TÜRE

\section{Distribution of respiratory viral agents in patients being followed-up in our pediatric emergency department}

\author{
Esra TÜRE ${ }^{1}$, Abdullah YAZAR ${ }^{1}$
}

\begin{abstract}
We aimed to determine the distribution of frequency of respiratory viruses detected in nasopharyngeal swab samples of patients under 5 years of age, who were hospitalized in the inpatient unit of pediatric emergency department during last year, by seasons, age and clinical findings. Hospitalization files of the patients were examined retrospectively. Patients' age, gender, admission complaint, physical examination findings, season they admitted, need for non-invasive mechanical ventilation, duration of hospital stay and result of nasopharyngeal swab viral polymerase chain reaction (PCR) were recorded. When results of the nasopharyngeal swab viral PCR of the patients were examined, it was determined that no virus was isolated in $43(26.5 \%)$ patients and in $119(73.5 \%)$, however, at least one virus was isolated. Of these 119 patients; only one virus was detected in $82(68.9 \%)$ and two or more viruses in $37(31.1 \%)$. It was observed that $87(53.7 \%)$ did not receive any antibiotics and $75(46.3 \%)$ patients were treated with one or more antibiotics. Early detection of viral pathogens is thought to prevent unnecessary antibiotic use, control of antibiotic resistance, shorten hospital stay and decrease treatment costs.
\end{abstract}

Article Info

Received:11.12.2018

Accepted: 02.01.2019

Online Published:31.03.2019

DOI: $10.26453 /$ otjhs.495639

Keywords: Respiratory tract infection, nasopharyngeal swab, viral PCR, child

${ }^{1}$ Department of Pediatric Emergency, Meram Medical Faculty, Necmettin Erbakan University, Konya, Turkey

\section{INTRODUCTION}

Acute respiratory tract infections (ARTI) are among the most common infectious diseases in developing countries and also one of the leading causes of morbidity and mortality. ${ }^{1}$ ARTI are responsible for deaths of four and a half million children annually in the world and account for $30 \%$ of childhood deaths. ${ }^{2}$

Most upper respiratory tract infections (URTI) are of viral origin with main responsible agents being human rhinoviruse (RV), parainfluenza viruse (PIV), coronavirus, adenovirus, respiratory 
syncytial virus (RSV), enteroviruses, human metapneumovirus (hMPV) and influenza virus. ${ }^{3}$ hMPV has been recently identified in samples obtained from RSV - negative children with bronchiolitis. ${ }^{4}$ Importance of all viral agents at early ages is not clear; however, RSV, RV, PIV and influenza virus are more predominant in younger age group in the literature. ${ }^{5}$ While a microbiological agent involved in etiology cannot be detected in $40 \%-60 \%$ of community-acquired lower respiratory tract infections (LRTI), viral agents are commonly blamed. ${ }^{6}$ Isolated microbiological agents include influenza virus, PIV, adenovirus and RSV. ${ }^{7}$

In our study, we aimed to determine the frequency of respiratory viruses detected in nasopharyngeal swab samples of patients under 5 years of age, with signs of a respiratory tract infection by seasons, age and clinical findings.

\section{MATERIAL AND METHOD}

Patients under 5 years of age who admitted to pediatric emergency department of Necmettin Erbakan University Meram Faculty of Medicine with signs and symptoms of respiratory tract infections and from whom a nasopharyngeal swap sample was obtained between September 2017 and September 2018 were included in the study. After an approval from ethics committee, records and hospitalization files of the patients were examined retrospectively.
Patients' age, gender, admission complaint, physical examination findings, season they admitted, status of having any additional disease, method of oxygen support, need for non-invasive mechanical ventilation, duration of hospital stay and result of nasopharyngeal swab viral polymerase chain reaction (PCR) analysis were recorded.

Nasopharyngeal swab samples were obtained by inserting the swab into patients' nostrils until the posterior nasopharyx has been reached and then turning the swabs $360^{\circ}$. Swabs were kept in screw-capped tube containing transport medium and ultimately studied by real-time and multiplex PCR method. The method used could detect 20 respiratory pathogens at once (Influenza A, seasonal H1N1, Influenza B, RV, PIV 1-2-3-4, coronavirus 229E-NL63-OC43-HKU1, adenovirus, RSV A-B, enterovirus, hMPV A-B, parechovirus, bocavirus).

\section{Statistical analysis}

Statistical analysis was performed by using the Statistical Package for the Social Sciences for Windows ver. 20.0 package program. Continuous variables were represented as "mean \pm standard deviation". For distribution and frequency analyses of the data, descriptive analyses were used; in frequency data, for comparison of two independent groups, Chi-Square tests were used. For all statistical analyses, level of significance was considered to be $\mathrm{p}<0.05$. 


\section{RESULTS}

9498 patients had admitted with signs and symptoms of a respiratory tract in the study period. $162(1.7 \%)$ patients, those who were hospitalized in the inpatient unit and a nasopharyngeal swab sample was obtained were included in the study. Of the patients; 86 (53.1\%) were male and $76(46.9 \%)$ were female, and mean age was $1.69 \pm 1.43(0.2-5$ years, median: 1.16).

Age distribution revealed that $81(50 \%)$ were $<1$ years of age, $51(31.5 \%)$ were $1-3$ years of age and $30(18.5 \%)$ were $3-5$ years of age. The most common complaint was coughing in $98(60.5 \%)$ patients and this was followed bynasal discharge, discomfort, fever and loss of appetite according to frequency ranking. When physical examination findings of patients were examined, it was observed that prolonged expiration was the most common in $51(31.5 \%)$ patients and this was followed by crepitant rales, ronfulan rales, sibilant rales, participation of accessory respiratory muscles in respiration and cyanosis. No statistical significance was determined between admission complaints and physical examination findings, and gender and age groups $(p>0.05)$. Winter was the admitted season which was in $82(50.6 \%)$ patients (Table 2). 104 (64.2\%) of the patients were found to have a history of contact with another individual with common cold.

When results of the nasopharyngeal swab viral PCR analysis of the patients were examined, it was determined that no virus was isolated in 43 (26.5\%) patients and at least one virus was isolated in 119 (73.5\%). Of these 119 patients; only one virus was detected in $82(68.9 \%)$ and two or more viruses in $37(31.1 \%)$. Results of nasopharyngeal swab viral PCR are given in Figure 1. Mean hospitalization duration was $44.80 \pm 29.22$ hours. 62 patients $(38.3 \%)$ had been hospitalized for <24 hours, 56 (34.6\%) for $25-48$ hours, $26(16 \%)$ for $49-72$ hours and $18(11.1 \%)$ for $>72$ hours. $16(9.9 \%)$ patients had received continuous positive airway pressure support, 13 (8.0\%) high-flow nasal cannula oxygen support and $5(3.1 \%)$ bilevel positive airway pressure support. $87(53.7 \%)$ patients did not receive any antibiotic and 75 (46.3\%) patients, however, had been treated with one or multiple antibiotics. The most commonly used antibiotic was ampicillinsulbactam in $52(32.1 \%)$ patients and this was followed by, in order of frequency, oseltamivir (25.3\%), cefotaxime (13.6\%), clarithromycin (6.2\%) and amoxicilline clavulinic acid (3.7\%).

When durations of hospital stay of the patients were examined by age groups, it was determined that $9(50 \%)$ of 18 patients that were hospitalized for more than 72 hours were comprised of patients under one year of age which was statistically significantly $(\mathrm{p}=0.004)$. The most common isolated virus was RSV (38.9\%) in these patients which was also statistically significant $(\mathrm{p}=0.001)$.

The type of oxygen treatments were examined by age groups. This analysis revealed that $6(46.2 \%)$ 
of 13 patients that received high-flow nasal cannula oxygen support were significantly comprised of children under one year of age $(p=0.001)$. When distribution of viral pathogens was examined by age groups, it was determined RSV A and influenza A virus were significantly more common under one year of age and rhinovirus was significantly more common over three years of age $(p=0.001)$ (Table 1). No statistical significant difference was determined between gender and viral pathogens $(p>0.05)$.

$35(21.6 \%)$ of the patients were found to have an additional chronic disease. The most common accompanying chronic disease was cerebral palsy (n:14 40\%). Although not statistically significant, $19(54.3 \%)$ of the patients with a chronic disease were under one year of age. Admission time (season) was also analysed according to age groups.It was determined that $51(62.2 \%)$ of 81 patients admitted during winter was statistically significantly comprised of children under one year of age $(p=0.017)$. When distribution of durations of hospitalization were examined by seasons, it was determined that $13(72.2 \%)$ of 18 patients that stayed more than 72 hours admitted statistically significantly in winter months. $(\mathrm{p}=0.002)$. No statistical significance was determined between non-invasive mechanical ventilator or high-flow nasal cannula oxygen use and season of admission ( $p>0.05)$. Seasonal distribution of viral pathogens revealed that rhinovirus, influenza A virus and Rhinovirus + RSV A + RSV B coexistence were detected statistically significantly most common during winter, and RSV A, however, more common during autumn $(\mathrm{p}=0.001)$ (Table 2).

\section{DISCUSSION and CONCLUSION}

ARTI are not only one of the most common infectious diseases, but also an important public health problem. They are one of the leading causes of morbidity and mortality especially in developing countries and reputed to cause death of five million patients annually among young children under five years of age. Viral ARTI are more common among children compared to adults. ${ }^{89}$ Detection of viral pathogens in ARTI has a critical importance not only for initiation to treatment without losing any time, but also for avoidance of unnecessary use of antibiotics. ${ }^{10}$ In this study distribution of respiratory viruses detected in nasopharyngeal swab samples of patients with ARTI was examined by frequency, season, age and clinical findings.

In recent studies, detection rate of respiratory viruses in pediatric age group with ARTI seems to differ between $30-96 \% .{ }^{11,12}$ When the studies from our country were examined various rates had been examined. This rate was $35.4 \%$ among pediatric patients with ARTI in Cicek et al's study, ${ }^{13} 41.8 \%$ among pediatric patients with LRTI in Akcali et al.'s study ${ }^{14}$ and $29.8 \%$ among pediatric patients with URTI in Unuvar et.al's study. ${ }^{15}$ In previous studies; RSV was detected by 15-40\%, RV 24\%, PIV 6-7\%, adenovirus 7\%, influenza viruses $4-5 \%$ with seasonal and 
regional variations, coronavirus by $10-15 \%$, hMPV by $2-12 \%$ and bocavirus by $1-5 \%{ }^{8,16}$ In our study, it was observed that at least one virus was isolated in $73.5 \%$ of the patients. It is observed that positivity rates of respiratory viruses greatly varied between studies. This is thought to be due to age groups, underlying diseases, life conditions, epidemiological characteristics, environmental factors and endemias occurring during different periods of time.

It is known that ARTI is prevalent in childhood and that its prevalence decreases with advancing age. In a previous study, it was determined that of the virus-infected patients; $32.5 \%$ were under 1 year of age, $37.7 \%$ 1-3 years of age, $17.2 \%$ 3-6 years of age, $7.3 \%$ 6-10 years of age and $1.9 \%$ over 10 years of age. Although there is not many studies investigating the distribution of children with ARTI by gender, it is possible to say that it is more common among boys. ${ }^{17}$ Consistently with the literature, it was determined that majority of the patients was comprised of younger children under three years of age and that ratio of boys was higher in our study. It is known that viruses known to cause ARTI exhibit seasonal characteristics and the periods they peak vary between years. In previous studies, respiratory viruses have been reported to be isolated especially during winter months in Northern Hemisphere. ${ }^{18}$ Also in our study, it was similarly observed that $50.6 \%$ of our patients had admitted during winter.
Viral respiratory tract infection rates among children vary between $1 \%$ and $40 \% .{ }^{19}$ It has been reported that in these infections, most commonly isolated one is RSV and that most commonly accompanying viruses are adenovirus, bocavirus and Influenza A. ${ }^{11}$ In our study, the most commonly isolated virus was similarly RSV and this was followed by rhinovirus. In the study of Lim et al, ${ }^{19}$ it was demonstrated that there was no difference between disease severity of children with LRTI according to number of isolated viruses (one or more different viral agent). Consistently with the literature, in our study, more than one virus was isolated in $31.1 \%$ of the patients and no difference was determined in duration of hospitalization or non-invasive mechanical ventilator support when compared with patients where only one virus was isolated. In the study of Hall et al. ${ }^{20}$ hospitalization rates of RSV-positive patients were determined to be three-fold higher compared to those with influenza or parainfluenza viruses. In our study, $1 / 3$ of patients who were followed-up more than 72 hours at the hospital were similarly comprised of patients with RSV infection.

ARTI is the most common infectious disease that primary care physicians and emergency departments face all over the world. To achieve symptomatic relief antipyretics, analgesics, decongestants, and although not required antibiotics are frequently prescribed. Most URTI are known to be of viral origin; however, there are more than 20 bacterial and viral agents which are known to cause LRTI. As these cannot be differentiated by clinical examinations, diagnostic 
tests are required in order to prevent unnecessary use of antibiotics. ${ }^{21}$ In a study from our country on antibiotic use rate in ARTI, antibiotic prescription rate was found to be $47.5 \%$ in all RTI and total cost of antibiotics was determined to be $76.44 \% .^{22}$ In the study of Sert et al. ${ }^{23}$ in our region the most common cause of communityacquired pneumonia was determined to be viruses and unnecessary use of antibiotics was emphasized. Also in our study, total ratio of antibacterial and antiviral medications was, similarly, observed to be $46.3 \%$. While rate of Oseltamivir treatment was $25.3 \%$, it was observed that antibacterial treatment was added on this antiviral treatment in great majority of patients. High rates of antibiotic treatment despite of performing nasopharyngeal swab viral PCR tests for the patients indicate how difficult is to change pre-existing habits. These results reveal importance of continuous participation of physicians in in-service trainings and of their education on smart use of antibiotics.

In conclusion, it is an expected situation that unnecessary use of antibiotics in patients with ARTI may be prevented by determination of viral pathogens. Additionally, antibiotic resistance can thus be kept under control, duration of hospital stay will be shortened and treatment costs will be reduced with early establishment of diagnosis and appropriate treatment practices. However, large multi-center studies are needed for both regional and national annual respiratory virus distribution for prediction of potential endemias and epidemias.

\section{REFERENCES}

1. Bangladesh D. National Institute of Population Research and Training (NIPORT), Mitra and Associates, and Macro International.(2009). Calverton, Maryland: Bangladesh Demographic and Health Survey. 2007.

2. Gwatkin DR. How many die? A set of demographic estimates of the annual number of infant and child deaths in the world. Am J Public Health. 1980;70(12):1286-1289.

3. Kistler A, Avila PC, Rouskin S, et al. Panviral screening of respiratory tract infections in adults with and without asthma reveals unexpected human coronavirus and human rhinovirus diversity. J Infect Dis. 2007;196(6):817-825

4. van den Hoogen BG, de Jong JC, Groen J, et al. A newly discovered human pneumovirus isolated from young children with respiratory tract disease. Nat Med. 2001;7(6):719-724.

5. Mahony JB. Detection of respiratory viruses by molecular methods. Clin Microbiol Rev. 2008;21(4):716-747.

doi:

\subsection{8/CMR.00037-07.}

6. Alto WA. Human metapneumovirus: a newly described respiratory tract pathogen. J Am Board Fam Pract. 2004;17(6):466-469.

7. Iwane MK, Edwards KM, Szilagyi PG, et al. Population based surveillance for hospitalizations associated with respiratory 
syncytial virus, influenza virus, and parainfluenza viruses among young children. Pediatrics. 2004;113(6):1758-1764.

8. Tregoning JS, Schwarze J. Respiratory viral infections in infants: causes, clinical symptoms, virology, and immunology. Clin Microbiol Rev. 2010;23(1):74-98. doi: 10.1128/CMR.00032-09.

9. Kesson AM. Respiratory virus infections. Paediatr Respir Rev. 2007;8(3):240-248.

10. Advani S, Sengupta A, Forman M, Valsamakis A, Milstone AM. Detecting respiratory viruses in asymptomatic children. Pediatr Infect Dis J. 2012;31(12):1221-1226. doi:10.1097/INF.0b013e318265a804.

11. Goka EA, Vallely PJ, Mutton KJ, Klapper PE. Single and multiple respiratory virus infections and severity of respiratory disease: a systematic review. Paediatr Respir Rev. 2014;15(4):363-370.

doi:

10.1016/j.prrv.2013.11.001.

12. Leekha S, Irish CL, Schneider SK, et al. Viral detection using a multiplex polymerase chain reaction-based assay in outpatients with upper respiratory infection. Diagn Microbiol Infect Dis. 2013;75(2):169-173. doi:10.1016/j.diagmicrobio.2012.10.016.

13. Çiçek C, Arslan A, Karakuş HS, et al. Prevalence and seasonal distribution of respiratory viruses in patients with acute respiratory tract infections, 2002-2014. Mikrobiyol Bul. 2015;49(2):188-200.
14. Akçalı S, Yılmaz N, Güler Ö, Şanlidă̆ T, Anıl M. Alt solunum yolu enfeksiyonu olan çocuklarda solunum yolu viral etkenlerinin s1klığı. Turk Arch Ped 2013;48(3):215-220.

15. Ünüvar E, Yildiz I, Kiliç A, et al. Viral etiology and symptoms of acute upper respiratory tract infections in children. Turk $\mathbf{J}$ Med Sci. 2009;39(1):29-35.

16. Zhang D, He Z, Xu L, et al. Epidemiology characteristics of respiratory viruses found in children and adults with respiratory tract infections in southern China. Int J Infect Dis. 2014;25:159-164.

doi: 10.1016/j.ijid.2014.02.019.

17. Tsai HP, Kuo PH, Liu CC, Wang JR. Respiratory viral infections among pediatric inpatients and outpatients in Taiwan from 1997 to 1999. J Clin Microbiol. 2001;39(1):111-118.

18. Eccles R. An explanation for the seasonality of acute upper respiratory tract viral infections. Acta Otolaryngol. 2002;122(2):183-191.

19. Lim FJ, de Klerk N, Blyth CC, Fathima P, Moore HC. Systematic review and metaanalysis of respiratory viral coinfections in children. Respirology. 2016;21(4):648-655. doi: 10.1111/resp.12741.

20. Hall CB, Weinberg GA, Iwane MK, et al. The burden of respiratory syncytial virus infection in young children. $\mathrm{N}$ Engl $\mathrm{J}$ Med. 2009;360(6):588-598. doi: 
21. Templeton KE. Why diagnose respiratory viral infection? J Clin Virol. 2007;40(1):2-4. doi: 10.1016/S1386-6532(07)70002-1.

22. Yalçın A, Tosun E, Topaloğlu O. Solunum yolu enfeksiyonları: antibiyotik kullanım oranı ve tedavi maliyeti. Türk Aile Hek Derg. 2008;12(1):25-30.
23. Sert A, Keşli R, Odabaş D, et al. Identification of respiratory viral infection agents by multiplex real-time PCR among children hospitalized for community-acquired pneumonia in Konya province. Turk Hij Den Biyol Derg,2012;69(2):53-60. 


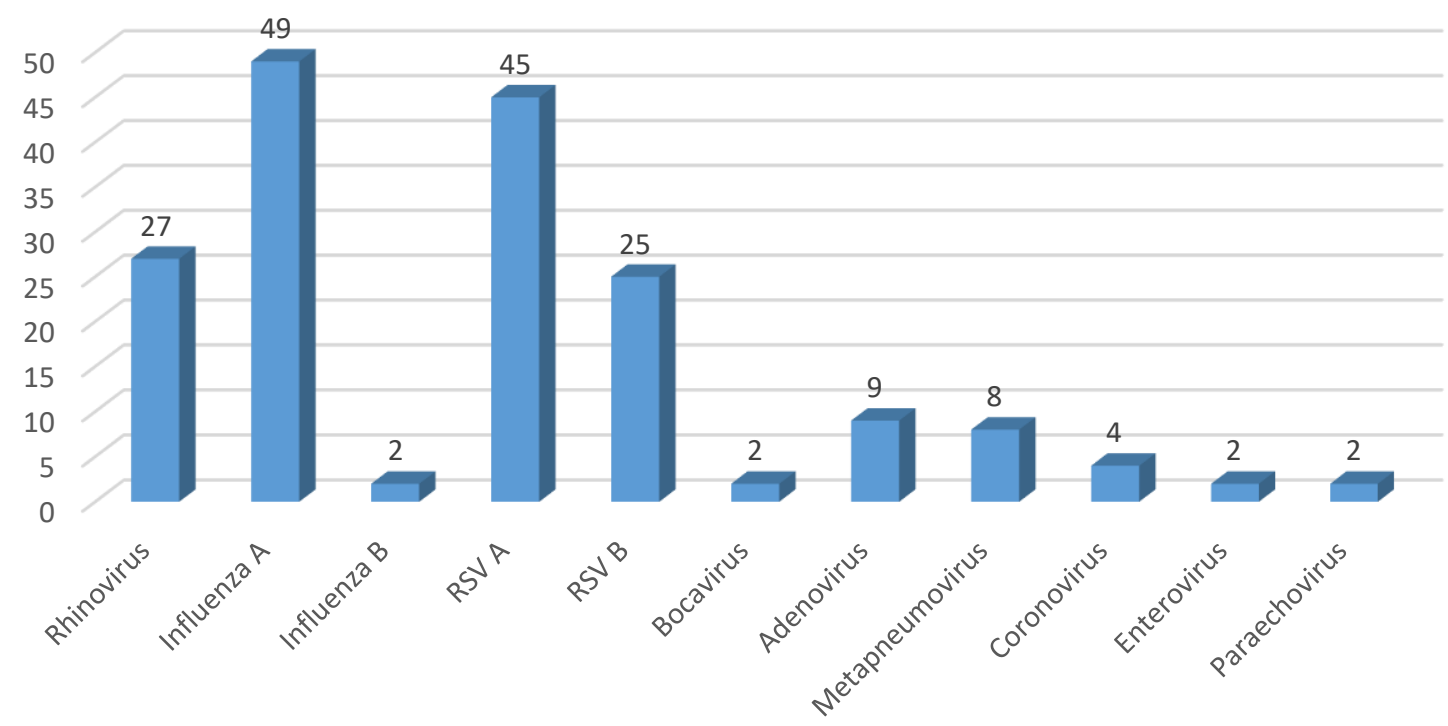

Figure 1. Results of nasopharyngeal swab viral PCR study 
Table 1. Distribution of viral agents by age groups

\begin{tabular}{lccccccc}
\hline & \multicolumn{2}{c}{$\begin{array}{c}\text { years of } \\
\text { age }\end{array}$} & \multicolumn{2}{c}{$\begin{array}{c}\mathbf{1 - 3} \text { years of } \\
\text { age }\end{array}$} & \multicolumn{2}{c}{$\mathbf{3}$ years of age } & p \\
& $\mathbf{n}$ & $\mathbf{\%}$ & $\mathbf{n}$ & $\mathbf{\%}$ & $\mathbf{n}$ & $\mathbf{\%}$ & \\
\hline Rhinovirus & 0 & 0 & 2 & 25 & 6 & 75 & $<\mathbf{0 . 0 0 1}$ \\
RSV A & 12 & 60 & 7 & 35 & 1 & 5 & $<\mathbf{0 . 0 0 1}$ \\
Influenza A & 29 & 61.7 & 11 & 23.4 & 7 & 14.9 & $<\mathbf{0 . 0 0 1}$ \\
Adenovirus & 2 & 66.7 & 1 & 33.3 & 0 & 0 & $>0.05$ \\
Metapneumovirus & 4 & 100 & 0 & 0 & 0 & 0 & $>0.05$ \\
RSV A+RSV B & 4 & 33.3 & 4 & 33.3 & 4 & 33.3 & $>0.05$ \\
Rhinovirus+RSV A+RSV B & 3 & 27.3 & 4 & 36.4 & 4 & 36.4 & $>0.05$ \\
Rhinovirus+Bocavirus & 2 & 100 & 0 & 0 & 0 & 0 & $>0.05$ \\
Rhinovirus+Adenovirus & 2 & 100 & 0 & 0 & 0 & 0 & $>0.05$ \\
Adenovirus+Metapneumovirus A+B & 4 & 100 & 0 & 0 & 0 & 0 & $>0.05$ \\
RSV A+RSV B+Coronavirus & 0 & 0 & 2 & 100 & 0 & 0 & $>0.05$ \\
Rhinovirus+Enterovirus+Paraechovirus & 0 & 0 & 0 & 0 & 2 & 100 & $>0.05$ \\
Rhinovirus+Influenza B & 2 & 100 & 0 & 0 & 0 & 0 & $>0.05$ \\
\hline
\end{tabular}


Table 2. Distribution of viral agents by seasons

\begin{tabular}{lccccccccc}
\hline & \multicolumn{2}{c}{ Spring } & \multicolumn{2}{c}{ Summer } & \multicolumn{2}{c}{ Autumn } & Winter & p \\
& $\mathbf{n}$ & $\boldsymbol{\%}$ & $\mathbf{n}$ & $\boldsymbol{\%}$ & $\mathbf{n}$ & $\boldsymbol{\%}$ & $\mathbf{n}$ & $\boldsymbol{\%}$ & \\
\hline Rhinovirus & 0 & 0 & 2 & 25 & 2 & 25 & 4 & 50 & $<\mathbf{0 . 0 0 1}$ \\
RSV A & 5 & 25 & 2 & 10 & 8 & 40 & 5 & 25 & $<\mathbf{0 . 0 0 1}$ \\
Influenza A & 8 & 17 & 4 & 8.5 & 9 & 19,1 & 26 & 55.3 & $<\mathbf{0 . 0 0 1}$ \\
Adenovirus & 0 & 0 & 0 & 0 & 3 & 100 & 0 & 0 & $>0.05$ \\
Metapneumovirus & 0 & 0 & 0 & 0 & 1 & 25 & 3 & 75 & $>0.05$ \\
RSV A+RSV B & 5 & 41.7 & 0 & 0 & 6 & 50 & 1 & 8.3 & $>0.05$ \\
Rhinovirus+RSV A+RSV B & 0 & 0 & 0 & 0 & 2 & 18.2 & 9 & 81.8 & $<\mathbf{0 . 0 0 1}$ \\
Rhinovirus+Bocavirus & 0 & 0 & 0 & 0 & 0 & 0 & 2 & 100 & $>0.05$ \\
Rhinovirus+Adenovirus & 0 & 0 & 0 & 0 & 0 & 0 & 2 & 100 & $>0.05$ \\
Adenovirus+Metapneumovirus A+B & 0 & 0 & 0 & 0 & 0 & 0 & 4 & 100 & $>0.05$ \\
RSV A+RSV B+Coronavirus & 0 & 0 & 0 & 0 & 0 & 0 & 2 & 100 & $>0.05$ \\
Rhinovirus+Enterovirus+Paraechovirus & 0 & 0 & 2 & 100 & 0 & 0 & 0 & 0 & $>0.05$ \\
Rhinovirus+Influenza B & 0 & 0 & 0 & 0 & 0 & 0 & 2 & 100 & $>0.05$ \\
\hline
\end{tabular}

